\title{
Role of Vasoactive Amines in the Antitumor Activity of Endotoxin
}

\author{
Nanne Bloksma ${ }^{1}$, C. Frieke Kuper ${ }^{2}$, Frans M. A. Hofhuis ${ }^{1}$ and Jan M. N. Willers ${ }^{1}$ \\ ${ }^{1}$ Department of Immunology, Laboratory of Microbiology, State University of Utrecht and ${ }^{2}$ Division for Nutrition and Food Research \\ TNO, Institute CIVO Toxicology and Nutrition, Zeist, The Netherlands
}

(Received 8 July 1983; accepted 1 March 1984)

\begin{abstract}
To estimate a possible role of vasoamines in the antitumor action of endotoxin, effects of isoproterenol, serotonin and adrenaline on subcutaneously transplanted murine Meth A sarcoma and the capacity of these agents to elicit antitumor factors were studied. Macroscopically all agents induced tumor necrosis and a temporal tumor growth stop, but only endotoxin was capable of induction of complete tumor regression. Histology showed that all agents induced hyperemia by $4 \mathrm{~h}$ and hemorrhagic necrosis by 24 h. The latter was located superficially at the outside of the tumors. Only serotonin and especially endotoxin induced substantial nonhemorrhagic necrosis in the remaining part of the tumors. Endotoxin induced a profound inhibition of the mitotic activity within the tumor, the effect of other agents was considerably less. Only endotoxin induced high levels of tumor necrosis factor, heat stable cytostatic factors and interferon in the circulation of mice treated with Corynebacterium parvum 14 days earlier.

It is concluded that these and other data provide indirect but circumstantial evidence for a role of vasoamines in the induction of hyperemia and hemorrhagic necrosis by endotoxin. The latter two effects are probably causally related. It is suggested that non-toxic vasoamines may be useful adjuvants to other treatments of cancer.
\end{abstract}

Key words: Antitumor action; Catecholamines; Endotoxin; Serotonin; Tumor necrosis factor; Vasoamines

\section{Introduction}

The potency of endotoxin to cause necrosis and regression of tumors is well known for many years (Gratia and Linz, 1931; Shear et al., 1943; Nowotny et al., 1971; Parr et al., 1973). Effects are indirect and mediated by the host (Shapiro, 1940; Männel et al., 1979). According to Carswell et al. (1975) induction of tumor damage may be mediated by tumor necrosis factor (TNF). TNF is present in sera from mice sequentially treated with Corynebacterium parvum and endotoxin and mimics the antitumor effects of endotoxin. Recently we found that induction of necrosis and regression by endotoxin was inhibited by prior administration of the $\alpha$-adrenergic receptor blocking agents phentolamine and phenoxybenzamine but not the $\beta$-receptor antagonist propranolol (Bloksma et al., 1982a). On histological examination it was found that phen- oxybenzamine completely prevented induction of hemorrhagic necrosis, but substantial non-hemorrhagic necrosis remained apparent (Kuper et al., 1982). This suggests that endotoxin induced two kinds of tumor necrosis and that hemorrhagic necrosis may be mediated by an adrenergic mechanism. As phenoxybenzamine and phentolamine not only antagonize reactions at $\alpha$-receptors but also reactions at serotonin receptors, a serotonergic mechanism might also be involved. This approach is supported by earlier findings that adrenaline and serotonin are released upon injection of endotoxin (Rosenberg et al., 1959) and that both agents induce tumor damage in a mouse sarcoma (Pradhan et al., 1957).

Abbreviations: PBS, phosphate-buffered saline; NMS, normal mouse serum; TNF, tumor necrosis factor; TNS, tumor necrosis serum. 
The aim of this study is to compare the histopathology of necrosis of Meth A sarcoma induced by endotoxin with those induced by agents acting at $\alpha, \beta$ or serotonin receptors, namely adrenaline, isoproterenol and serotonin. As previous experiments have shown that endotoxin-induced release of TNF and especially interferon was impaired by $\alpha$-receptor antagonists (Bloksma et al., 1982b) the capacity of the agonists to elicit these factors was studied too.

\section{Materials and Methods}

\section{Materials}

The following drugs were used: L-adrenaline ( $\mathrm{L}-$ epinephrine), L-isoproterenol hydrochloride and serotonin (5-hydroxytryptamine. $\mathrm{HCl}$ ) all from Sigma Chemical Company (St. Louis, MO, U.S.A.); endotoxin (LPSw from E. coli 0111:B4) from Difco Laboratories (Detroit, MI, U.S.A.) and Corynebacterium parvum (Coparvax Lot CA 761) from The Wellcome Research Laboratories (Beckenham, Kent, U.K.). All agents but adrenaline were administered intravenously (i.v.) in $0.5 \mathrm{ml}$ saline. Adrenaline was dissolved in phosphate-buffered saline (PBS) and a few drops of $0.1 \mathrm{~N} \mathrm{HCl}$. The $\mathrm{pH}$ was adjusted to 7.0 with $0.1 \mathrm{~N} \mathrm{NaOH}$.

\section{Animals and tumors}

Sera were prepared in female Swiss random mice of about 12 weeks of age (mean weight $30 \mathrm{~g}$ ) obtained from the Central Institute for the Breeding of Laboratory Animals (CPB, Zeist, The Netherlands). Tumor experiments were performed on female BALB/c inbred mice of the same age (mean weight $20 \mathrm{~g}$ ). They were bred and maintained in our own facilities. The Meth A fibrosarcoma, syngeneic to BALB/c mice, was obtained from the Clinical Research Centre (Harrow, Middlesex, U.K.) and was maintained by serial intraperitoneal passage. Cells from 5-6-day old transplants were harvested in Eagle's minimal essential medium and washed three or more times by centrifugation to remove erythro- cytes. Cell viability was determined by trypan blue exclusion.

\section{Preparation of the sera}

Tumor necrosis serum (TNS) was prepared according to Green et al. (1977). Mice received Corynebacterium parvum $(33 \mathrm{mg} / \mathrm{kg}$ body weight) i.v. followed by endotoxin $(1.25 \mathrm{mg} / \mathrm{kg}$ body weight) i.v. two weeks later. Serum was prepared from blood collected $90 \mathrm{~min}$ after endotoxin, pooled and stored at $-20^{\circ} \mathrm{C}$. Other sera were prepared by omission of C. parvum and/or substitution of endotoxin for adrenaline $(0.5 \mathrm{mg} / \mathrm{kg})$, isoproterenol $(10 \mathrm{mg} / \mathrm{kg})$, serotonin $(10 \mathrm{mg} / \mathrm{kg})$ or saline. Sera were heated $\left(56^{\circ} \mathrm{C}\right.$, $10 \mathrm{~min}$ ) prior to all assays excepting determination of interferon. TNF is stable at this temperature (Carswell et al., 1975).

\section{Tumor assays}

Mice received a subcutaneous injection with $10^{6}$ viable Meth A cells in the abdomen. After 9 days they were injected i.v. with a test agent. Tumor size was measured with a caliper and expressed as mean diameter (length + breadth/2). Necrosis was measured 2 days after injection and expressed as 100 times the quotient of the mean diameters of necrotic area and tumor. The in vitro cytostatic activity of the sera against Meth A cells was determined by measuring the incorporation of $\left[{ }^{3} \mathrm{H}\right]$ thymidine into the tumor cells after culture with serum for $40 \mathrm{~h}$ as described earlier (Bloksma et al., 1980).

\section{Histology}

Tumors were fixed in $4 \%$ phosphate-buffered formalin. Paraffin-embedded sections $(5 \mu \mathrm{m})$ made in dorso-ventral direction from the central part of the tumor were stained with hematoxylin-eosin and examined microscopically without previous knowledge of the treatment. Hyperemia was expressed as the number of vessel transections with a diameter of $\geqslant 20 \mu \mathrm{m} / \mathrm{section}$. Counts surmounting 60 were indicated with $>60$. Dividing tumor cells were counted with the aid of an ocular grid at $1000 \times$ 
magnification on 10 predetermined sites, representing all parts of the section.

\section{Quantitation of interferon}

Interferon was assayed by the plaque reduction method (Epstein and McManus, 1980) using mouse $L$ cells (clone 929) and vesicular stomatitis virus. Interferon titres were adjusted to the units of the reference mouse interferon standard 6002-902-026 (National Institutes of Health, Bethesda, MD, U.S.A.).

\section{Detection of endotoxin}

To exclude a possible role of contaminating endotoxin in the necrosis induced by serotonin, adrenaline and isoproterenol these preparations were investigated photometrically for the presence of endotoxin. Limulus amebocyte lysate (Associates of Cape Cod Inc., Woods Hole, MA, U.S.A.) was reconstituted with $2.5 \mathrm{ml}$ pyrogen-free distilled water. Standard endotoxin of the same company and chromogenic substrate S 2423 (KabiVitrum, Stockholm, Sweden) were reconstituted according to the manufacturers' directions. Equal volumes $(30 \mu \mathrm{l})$ of appropriately diluted samples in saline and Limulus amebocyte lysate reagent were incubated in flatbottomed wells of microtiter plates (96 wells; Greiner, Nürtingen, F.R.G.) at $37^{\circ} \mathrm{C}$ for $45 \mathrm{~min}$. After addition of $60 \mu$ of $S 2423$, plates were incubated for $4 \mathrm{~min}$ at $37^{\circ} \mathrm{C}$ followed by addition of $60 \mu \mathrm{l}$ glacial acetic acid. Absorbance was measured in a Titertek Multiskan photometer at $405 \mathrm{~nm}$. Endotoxin concentrations in the samples were read from the standard curve.

\section{Statistics}

When appropriate, data have been expressed as mean \pm SEM. Significance analysis was done by Student's $t$ test or the Mann-Whitney $U$ test (Siegel, 1959), indicated in the legend. $p$-values over 0.05 were considered not significant.

\section{Results}

Macroscopical antitumor effects of endotoxin and vasoactive amines

All agents but saline and PBS induced a marked reddening of the tumors $4 \mathrm{~h}$ after injection. Upon bisecting these tumors the cut surface was very bloody, which is indicative of hyperemia (Robbins and Cotran, 1979). Upon i.v. injection of endotoxin, a high incidence of extensive tumor necrosis could be observed by $24 \mathrm{~h}$. This was mostly followed by stagnation of tumor growth and sometimes by complete regression (Table I). Necrosis induced by isoproterenol and serotonin was less frequent and less extensive. Tumor growth was moderately inhibited and no regressions occurred. Nonlethal doses of adrenaline injected i.v. caused no tumor damage (data not shown), but administration of adrenaline into the tumor in a volume of $0.05 \mathrm{ml}$ caused necrosis with little consequences for tumor growth (Table I). To exclude a role of contaminating endotoxin in the necrosis induced by the vasoactive agents, the endotoxin content of these preparations was determined. The injected amount of these preparations contained less than $0.1 \mathrm{ng}$ of endotoxin corresponding with a potency of $<0.3$ EU of the control standard endotoxin. The vasoactive agents did not interfere with endotoxin determination as was assessed by use of endotoxinspiked preparations.

\section{Microscopical antitumor effects of endotoxin and vasoactive agents}

Tumor-bearing mice were injected with a necrotizing dose of endotoxin or vasoactive amines. Endotoxin and adrenaline caused a marked hyperemia by $4 \mathrm{~h}$, while isoproterenol and serotonin caused less effect (Table II). The hyperemia was mainly located on the ventral outside of the tumor and had disappeared by $24 \mathrm{~h}$. At that time hemorrhagic necrosis was observed at the same site. The extent of hyperemia and hemorrhagic necrosis corresponded very well. After injection of endotoxin severe non-hemorrhagic necrosis as judged by pyk- 
TABLE I

Necrosis, growth inhibition and regression of Meth A sarcoma induced by several agents

\begin{tabular}{|c|c|c|c|c|c|}
\hline \multirow[t]{2}{*}{ Agent } & \multirow{2}{*}{$\begin{array}{l}\text { Dose }^{\mathrm{a}} \\
(\mathrm{mg} / \mathrm{kg})\end{array}$} & \multicolumn{2}{|l|}{ Necrosis } & \multicolumn{2}{|c|}{ Incidence $^{b}$ of } \\
\hline & & Incidence $^{b}$ & Extent $^{c}$ & $\begin{array}{l}\text { Growth } \\
\text { inhibition }^{d}\end{array}$ & Regression \\
\hline Endotoxin & 1.25 & $9 / 10$ & $57 \pm 4$ & $8 / 10$ & $3 / 10$ \\
\hline Isoproterenol & $\begin{array}{r}5 \\
10\end{array}$ & $\begin{array}{l}1 / 5 \\
4 / 10\end{array}$ & $\begin{array}{l}38 \\
42 \pm 10\end{array}$ & $\begin{array}{l}0 / 5 \\
3 / 10\end{array}$ & $\begin{array}{l}0 / 5 \\
0 / 10\end{array}$ \\
\hline Serotonin & $\begin{array}{l}10 \\
30\end{array}$ & $\begin{array}{l}7 / 10 \\
6 / 10\end{array}$ & $\begin{array}{l}43 \pm 5 \\
47 \pm 4\end{array}$ & $\begin{array}{l}1 / 10 \\
4 / 10\end{array}$ & $\begin{array}{l}0 / 10 \\
0 / 10\end{array}$ \\
\hline Saline & - & $1 / 20$ & 37 & $0 / 20$ & $0 / 20$ \\
\hline Adrenaline & $\begin{array}{l}0.5 \\
0.15 \\
0.05\end{array}$ & $\begin{array}{c}10 / 10 \\
5 / 5 \\
3 / 5\end{array}$ & $\begin{array}{l}46 \pm 4 \\
47 \pm 3 \\
54 \pm 6\end{array}$ & $\begin{array}{l}3 / 10 \\
1 / 5 \\
1 / 5\end{array}$ & $\begin{array}{l}0 / 10 \\
0 / 5 \\
0 / 5\end{array}$ \\
\hline PBS & - & $0 / 10$ & & $0 / 10$ & $0 / 10$ \\
\hline
\end{tabular}

a I.v., except for adrenaline and PBS which were administered intratumorally

b Number of affirmative cases/total.

c (Mean diameter necrotic area/mean diameter tumor) $\times 100$.

d No increase of tumor size for at least 2 days after injection (observed exclusively in necrotic tumors).

e Complete disappearance of the tumor within 12 days after injection.

nosis, karyorrhexis and cytoplasmic eosinophilia was observed in the remaining part of the tumor sections. Tumor sections of mice treated with adrenaline or isoproterenol had no more non-hemorrhagic necrosis than control tumors, having over $50 \%$ vital tissue. Serotonin caused an intermediate effect.

The mitotic activity within the tumor was considerably reduced by endotoxin at both times. Serotonin inhibited to the same degree only by $4 \mathrm{~h}$. In all other instances less, but still considerable, inhibition of mitotic activity was induced when compared to saline-treated controls. In none of the sections could substantial inflammatory infiltrates be detected within the observation period.

In vivo and in vitro antitumor activity of sera from mice treated with tumor necrotizing agents

Injection of $0.5 \mathrm{ml}$ TNS into Meth A-bearing mice caused extensive tumor necrosis in all animals and complete regression in 4 out of 5 mice (Fig. 1). None of the sera of mice treated with $C$. parvum and an vasoactive agent caused serious tumor damage. Only a moderate necrosis in $20 \%$ of mice was observed on injection of sera of mice treated with C. parvum and adrenaline or isoproterenol. Normal mouse serum (NMS) and sera of mice merely treated with endotoxin, serotonin or adrenaline had no significant antitumor effect, but serum of isoproterenol-treated mice retarded tumor growth slightly.

The cytostatic activity of NMS against Meth A cells in vitro appeared to be high when compared to growth in medium alone (Fig. 2). Serum of mice treated with $C$. parvum was significantly more cytostatic than NMS, as were sera from mice merely treated with endotoxin, isoproterenol or serotonin. Compared to sera of mice treated with $C$. parvum alone, an additional injection with serotonin, isoproterenol or especially endotoxin enhanced cytostatic activity of the sera considerably. 
Induction of interferon by tumor necrotizing agents

Substantial levels of interferon could be detected in sera from mice treated with endotoxin $90 \mathrm{~min}$ earlier (Table III). Pretreatment with $C$. parvum augmented the interferon yield significantly. Elicitation of $C$. parvum-treated mice with isoproterenol or serotonin induced hardly more interferon than injection of saline. Isoproterenol tended to induce more interferon in normal than in C. parvum-treated mice. Adrenaline appeared incapable of inducing interferon.

\section{Discussion}

The antitumor action of vasoactive amines was investigated as to their possible involvement in the

TABLE II

Histology of Meth A sarcoma 4 and 24 h after i.v. administration of tumor necrotizing agents

\begin{tabular}{|c|c|c|c|c|c|c|}
\hline \multirow[t]{2}{*}{ Agent } & \multirow{2}{*}{$\begin{array}{l}\text { Dose } \\
(\mathrm{mg} / \mathrm{kg})\end{array}$} & \multirow[t]{2}{*}{ Time } & \multirow{2}{*}{$\begin{array}{l}\text { Hyperemia } \\
(\text { mean } \pm \text { SEM) }\end{array}$} & \multirow{2}{*}{$\begin{array}{l}\text { Mitotic } \\
\text { index }^{b} \\
(\text { mean } \pm \text { SEM })\end{array}$} & \multicolumn{2}{|c|}{ Hemorrhagic necrosis } \\
\hline & & & & & Incidence & Extent ${ }^{8}$ \\
\hline \multicolumn{7}{|l|}{ Experiment 1} \\
\hline \multirow[t]{2}{*}{ Endotoxin } & 1.25 & $4^{\mathrm{c}}$ & $>60 \pm 0^{\mathrm{d}}$ & $0.33 \pm 0.33$ & & \\
\hline & & 24 & $3 \pm 1$ & $0.00 \pm 0.00^{e}$ & $4 / 4$ & $9 \pm 3$ \\
\hline \multirow[t]{2}{*}{ Isoproterenol } & 10 & 4 & $31 \pm 6^{d}$ & $1.50 \pm 0.50$ & & \\
\hline & & 24 & $12 \pm 4$ & $1.45 \pm 0.48^{e}$ & $3 / 4$ & $4 \pm 0$ \\
\hline \multirow[t]{2}{*}{ Serotonin } & 10 & 4 & $>43 \pm 11$ & $0.25 \pm 0.25^{\mathrm{d}}$ & & \\
\hline & & 24 & $19 \pm 6$ & $1.75 \pm 0.48$ & $3 / 4$ & $6 \pm 1$ \\
\hline Saline & - & 24 & $6 \pm 3$ & $3.25 \pm 0.48$ & $0 / 4$ & \\
\hline \multicolumn{7}{|l|}{ Experiment 2} \\
\hline \multirow[t]{2}{*}{ Endotoxin } & 1.25 & 4 & $>60 \pm 0^{\mathrm{d}, \mathrm{e}}$ & $0.50 \pm 0.29^{e}$ & & \\
\hline & & 24 & $11 \pm 8$ & $0.00 \pm 0.00^{e}$ & $3 / 4$ & $12 \pm 4$ \\
\hline \multirow[t]{2}{*}{ Saline } & - & 4 & $9 \pm 5$ & $2.50 \pm 0.29$ & & \\
\hline & & 24 & $6 \pm 1$ & $3.00 \pm 0.41$ & $0 / 4$ & \\
\hline \multirow[t]{2}{*}{ Adrenaline $^{\mathrm{f}}$} & 0.5 & $4^{\mathfrak{c}}$ & $>60 \pm 0^{d, e}$ & $0.67 \pm 0.33^{e}$ & & \\
\hline & & 24 & $13 \pm 8$ & $1.75 \pm 0.25$ & $3 / 4$ & $15 \pm 11$ \\
\hline \multirow[t]{2}{*}{ PBS $^{f}$} & - & 4 & $3 \pm 1$ & $1.00 \pm 0.00^{\mathrm{e}}$ & & \\
\hline & & 24 & $17 \pm 8$ & $1.25 \pm 0.48^{e}$ & $0 / 4$ & \\
\hline
\end{tabular}

a Number of dilated vessel transections/section.

b Number of dividing cells $/ \mathrm{mm}^{2}$ tumor section.

c $n=3$.

d $p<0.03$ compared to $24 \mathrm{~h}$ ( $U$ test).

- $p<0.03$ compared to saline-elicited controls ( $U$ test).

f Administered into the tumor.

s (Mean diameter necrotic area/mean diameter tumor) $\times 100$. 


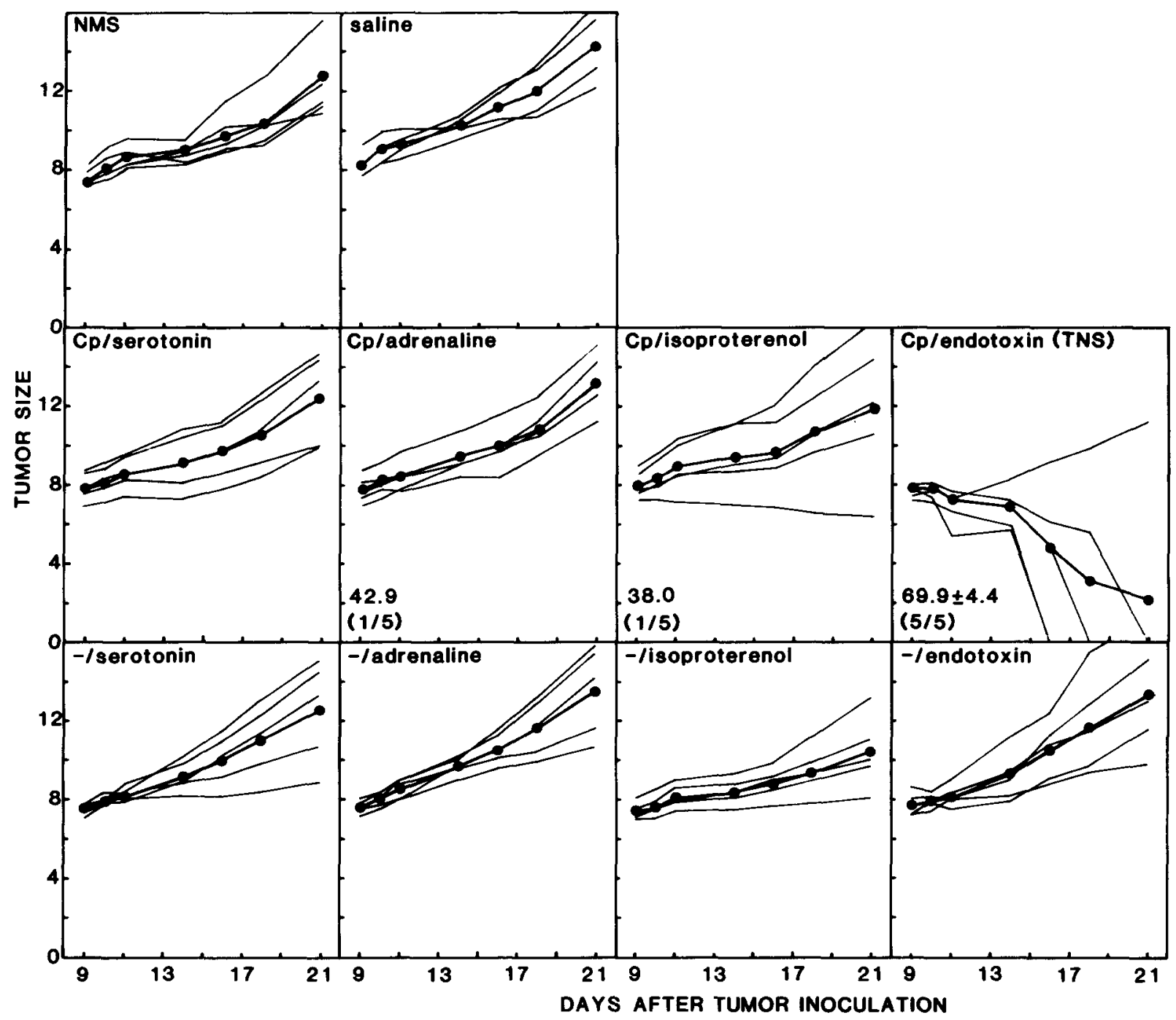

Fig. 1. Growth of Meth A sarcoma after i.v. injection of saline or $0.5 \mathrm{ml}$ of pooled serum of normal or Corynebacterium parvum (Cp)-treated mice elicited with a tumor necrotizing agent or saline (NMS). Thin lines indicate tumor size of individual mice. Heavy lines with circles indicate the mean of each group. Figures indicate the mean percentage of hemorrhagic necrosis \pm SEM and the incidence (in brackets).

antitumor action of endotoxin. Endotoxin induced necrosis of Meth A sarcoma mostly followed by growth inhibition. A number of tumors regressed completely. Isoproterenol, serotonin and adrenaline induced much less necrosis with only minor consequences as to tumor growth. The negligible quantities of endotoxin in these preparations, however, suggest that the effects observed are due to the vasoactive agents themselves.

Histology was in line with macroscopic effects.
Endotoxin caused stronger hyperemia and hemorrhagic necrosis and a more profound inhibition of mitotic activity, while extensive non-hemorrhagic necrosis was only induced by endotoxin. So at most part of the antitumor action of endotoxin might be mediated by vasoamines. The moderate tumor damage resulting from injection of high, unphysiological doses of vasoamines does not rule out a role of these agents in the antitumor action of endotoxin. Endotoxin is known to cause the release 


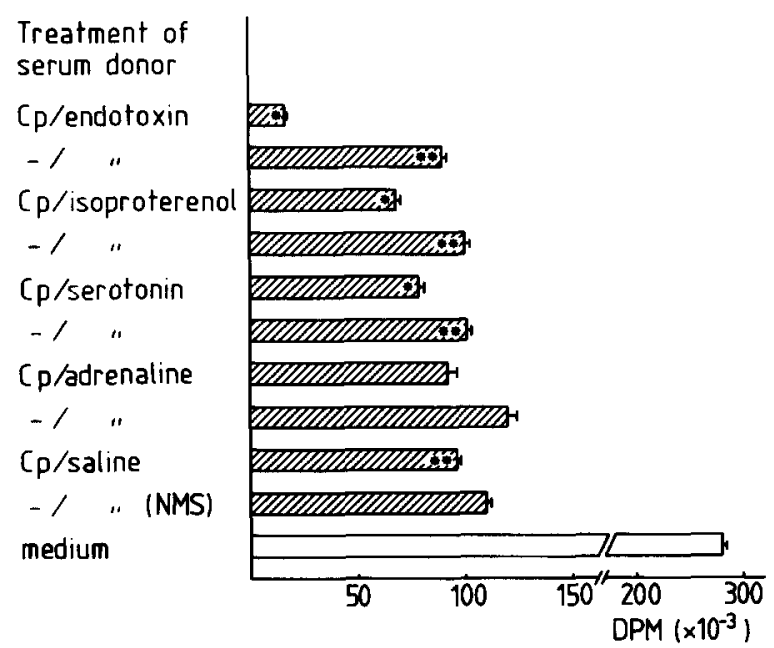

Fig. 2. Cytostatic activity on Meth A cells in vitro of sera of mice treated with Corynebacterium parvum $(\mathrm{Cp})$ and/or a tumor-necrotizing agent (shown as reduced $\left[{ }^{3} \mathrm{H}\right]$ thymidine incorporation). Sera of 6 mice were tested in quadruplicate for each group. ${ }^{*}, p<0.001$ ( $t$ test) compared to $\mathrm{Cp}$; 'saline. ${ }^{* *}, p<0.02$ compared to $-/$ saline (NMS). All necrotizing agents elicited stronger cytostatic activity in Cp-treated mice than in normal mice $(p<0.001)$.

TABLE III of various vasoamines (Rosenberg et al., 1959; Endo, 1982) and also to increase sensitivity to their effects (Kuratsuka et al., 1975; 1978). These properties and the well known synergic activity of different vasoamines (Munoz and Bergman, 1968; Foon et al., 1980) may endow endotoxin with the property to induce hemorrhagic necrosis. Besides this action, other properties of endotoxin, not innate to vasoamines, such as its strong immunoadjuvanticity and macrophage activating capacity, probably contribute to its activity. Interferon, TNF and cytostatic factors, when induced in the tumorbearing mouse, might also be involved. The amount of interferon found to be induced in tumor-bearing mice was shown to exert some activity in our Meth A system (Bloksma, 1982; Bloksma et al., 1983). However, we, and as far as we know others, have not been able to detect TNF in the circulation of endotoxin-injected Meth A-bearing mice, while the factor could not be absorbed from TNS by Meth A cells (Bloksma et al., 1984).

Determination of interferon in TNS and other sera

\begin{tabular}{|c|c|c|c|c|c|}
\hline \multirow{3}{*}{$\begin{array}{l}\text { Treatment of } \\
\text { serum donors } \\
\text { Cpa } / \text { endotoxin (TNS) }\end{array}$} & \multicolumn{5}{|c|}{ Interferon $(\mathrm{U} / 0.1 \mathrm{ml})$} \\
\hline & \multicolumn{4}{|c|}{ Individual mice } & \multirow{2}{*}{$\frac{\text { Mean }}{>5949^{\mathrm{c}, \mathrm{d}, \mathrm{e}}}$} \\
\hline & $>5952$ & $>5952$ & $>5952$ & 5939 & \\
\hline - /endotoxin & 4387 & 2785 & 2698 & 2079 & $2987^{\mathrm{c}, \mathrm{d}}$ \\
\hline $\mathrm{Cp} /$ isoproterenol & 158 & 135 & 118 & $<62$ & $<118$ \\
\hline - /isoproterenol & 629 & 322 & 301 & $<62$ & $<329$ \\
\hline $\mathrm{Cp} /$ serotonin & 249 & 135 & 125 & 100 & $152^{d}$ \\
\hline - /serotonin & 441 & $<62$ & 60 & 3 & $<142$ \\
\hline $\mathrm{Cp} /$ adrenaline & 93 & $<62$ & $<62$ & $-\mathbf{b}$ & $<72$ \\
\hline - /adrenaline & $<62$ & $<62$ & $<62$ & $-{ }^{b}$ & $<62$ \\
\hline $\mathrm{Cp} /$ saline & 316 & 64 & $<62$ & $<62$ & $<126$ \\
\hline - /saline & $<62$ & $<62$ & $<62$ & $<62$ & $<62$ \\
\hline
\end{tabular}

a Corynebacterium parvum.

b I.v. injection of adrenaline was lethal to the majority of the mice. Therefore 10 normal and $10 \mathrm{Cp}$-treated mice were injected with adrenaline. Only 3 mice of each group survived.

c Significantly different from $\mathrm{Cp} / \mathrm{saline} ; p=0.014$ ( $U$ test). For determination of significance values $<62$ and $>5952$ were equalized to 62 and 5952 respectively.

d Significantly different from -/saline; $p=0.014$.

e Significantly different from sera of mice not pretreated with $\mathrm{Cp} ; p=0.014$. 
The local vasodilating effect we observed after injection of adrenaline into Meth A is quite opposite to the usual effect of adrenaline in peripheral healthy tissue (Weiner, 1980). On the other hand, Wickersham et al. (1977) observed no response of tumor vessels to topically administered adrenaline and noradrenaline, and Hafström et al. (1980) reported enhanced blood perfusion of liver tumors in rats after injection of noradrenaline. This was attributed to the lack of smooth muscles and adrenergic nerves in the vessel walls of tumors (Krylova, 1969; Mattsson et al., 1977).

The endotoxin-induced vasodilation which preceded hemorrhagic necrosis in murine sarcomas and in adrenaline-prepared rabbit skin was shown to result in an almost complete to complete standstill of blood flow (Algire et al., 1947; Zweifach et al., 1956), suggesting that tissue damage is more or less due to ischemic hypoxia. A same mechanism may underlie hemorrhagic necrosis of tumors induced by adrenaline, isoproterenol and serotonin.

The absence of clear inflammatory infiltrates within the tumor $4 \mathrm{~h}$ as well as $24 \mathrm{~h}$ after injection of all agents, while tumor damage is overt at the later time, suggests that these effects are probably due to humoral mechanisms. Our data show that vasoamines may also exert antitumor activity by other means than recruitment of inflammatory cells into tumor tissue as suggested by others (Gershon et al., 1975; Lynch and Salomon, 1977; Askenase, 1977). The induction of tumor necrosis by the selective $\beta$-receptor agonist isoproterenol (Weiner, 1980 ) is seemingly in contrast with the observation that $\alpha$-but not $\beta$-adrenoceptor antagonists inhibited the induction of tumor necrosis by endotoxin (Bloksma et al., 1982a; Kuper et al., 1982). Different mechanisms are probably involved. Moreover, agonists at $\alpha$ - and $\beta$-receptors do not always elicit opposite reactions. Among others Beets and Paul (1980) showed that selective $\alpha$ - as well as $\beta$ adrenoceptor agonists induced identical vascular reactions in the guinea pig skin by entirely different mechanisms.

Several data point at a need for adrenaline and functional adrenergic receptors in the elicitation of TNF and interferon by endotoxin. TNF could not be elicited in adrenalectomized mice (C. Galanos, personal communication in Green et al., 1977). Further, induction of TNF and especially interferon could be inhibited by $\alpha$-adrenoceptor antagonists (Bloksma et al., 1982b), while administration of adrenaline shortly before endotoxin inhibited endotoxin-induced release of interferon (Jensen, 1969) and TNF (Bloksma et al., 1982b), suggesting tachyphylaxis. As TNF and interferon could not be elicited by adrenaline alone, this hormone may be needed to give a kind of permissive signal.

In conclusion, data of this and other papers provide only indirect evidence for a role of vasoamines in the induction of hyperemia and hemorrhagic necrosis by endotoxin. Non-toxic vasoactive agents such as serotonin may be useful adjuvants to other tumor therapies.

\section{Acknowledgements}

The authors are indebted to J. P. Bruyntjes and R. Vergeer for expert technical assistance and to J. G. Kreeftenberg (National Institute of Public Health, Bilthoven, The Netherlands) for advice on the Limulus assay. This study was supported by grant MB 78-13 of the Stichting Koningin Wilhelmina Fonds, Netherlands Cancer Foundation.

\section{References}

Algire GH, Legallais FY, Park HD (1947) Vascular reactions of normal and malignant tissues in vivo. II. The vascular reaction of normal and neoplastic tissues of mice to a bacterial polysaccharide from Serratia marcescens (Bacillus prodigiosus) culture filtrates. $J$ Natl Cancer Inst 8: 53.

Askenase PW (1977) Role of basophils, mast cells and vasoamines in hypersensitivity reactions with a delayed time course. Prog Allergy 23: 199.

Beets, JL, Paul W (1980) Actions of locally administered adrenoceptor agonists on increased plasma protein extravasation and blood flow in guinea-pig skin. Br J Pharmac 70: 461

Bloksma N (1982) Anti-tumour activities of endotoxin in the mouse. A focus on the role of tumour necrosis factor. PhD Thesis, State University of Utrecht, The Netherlands.

Bloksma, N, Schetters TP, Figdor C, Van Dijk H, Willers JM (1980) In vitro anti-tumour activity of tumour necrosis serum. Int J Immunopharmacol 2: 95. 
Bloksma N, Hofhuis FM, Willers JMN (1982a) Effect of adrenoceptor blockade on hemorrhagic necrosis of Meth A sarcomata induced by endotoxin or tumour necrosis serum. Immunopharmacology 4: 163.

Bloksma N, Hofhuis F, Benaissa-Trouw B, Willers J (1982b) Endotoxin-induced release of tumour necrosis factor and interferon is inhibited by prior adrenoceptor blockade. Cancer Immunol Immunother 14: 41.

Bloksma N, Kuper CF, Hofhuis FMA, Benaissa-Trouw B, Willers JMN (1983) Antitumour activity of endotoxin, concanavalin A and poly I:C and their ability to induce tumour necrosis factor, cytostatic factors and interferon in vivo. Cancer Immunol Immunother 16: 35.

Bloksma N. Hofhuis FMA, Willers JMN (1984) Role of mononuclear phagocyte function in endotoxin-induced tumor necrosis. Eur J Cancer Clin Oncol 20: 397.

Carswell EA, Old LJ, Kassel RL, Green S. Fiore N, Williamson B (1975) An endotoxin-induced serum factor that causes necrosis of tumors. Proc Natl Acad Sci USA 72: 3666.

Endo Y (1982) Simultaneous induction of histidine and ornithine decarboxylases and changes in their product amines following injection of Escherichia coli lipopolysaccharides into mice. Biochem Pharmacol 31: 1643.

Epstein LB, McManus NH (1980) Macro- and microassays for the antiviral effects of human and mouse interferons. In Manual of Clinical Immunology, 2nd edn. Eds. NR Rose, $\mathbf{H}$. Friedman. Washington: Am. Soc. Microbiol. pp. 275-283.

Foon KA, Wahl SM, Oppenheim JJ, Rosenstreich DL (1980) Serotonin-induced production of a monocyte chemotactic factor by human peripheral blood leukocytes. J Immunol 117 : 1545.

Gershon RK, Askenase PW, Gershon MD (1975) Requirement for vasoactive amines for production of delayed-type hypersensitivity skin reactions. $J$ Exp Med 142: 732.

Gratia A, Linz R (1931) Le phénomène de Shwartzman dans le sarcome du Cobaye. C R Séanc Soc Biol Ses Fil 108: 427.

Green S, Dobrjansky A, Chiasson MA, Carswell E, Schwartz MK, Old LJ (1977) Corynebacterium parvum as the priming agent in the production of tumor necrosis factor in the mouse. J Natl Cancer Inst 59: 1519.

Hafström L, Nobin A, Persson B, Sundqvist K (1980) Effects of catecholamines on cardiovascular response and blood flow distribution to normal tissue and liver tumors in rats. Cancer Res 40: 481.

Jensen MM (1969) The influence of vasoactive amines on interferon production in mice. Proc Soc Exp Biol Med 130: 34.

Krylova NV (1969) Characteristics of microcirculation in experimental tumours. Bibl Anat 10: 301.

Kuper CF, Bloksma N, Hofhuis FM, Bruyntjes JP, Willers JM (1982) Influence of adrenoceptor blockade on endotoxin-induced histopathological changes in murine Meth A sarcoma. Int J Immunopharmacol 4: 49.

Kuratsuka K, Homma R, Shimazaki Y, Funasaka I (1975) Rapid appearance of histamine sensitivity in mice by minute dose of endotoxins. Experientia 31: 206.
Kuratsuka, K, Shimazaki Y, Funasaka I, Watanabe Y (1978) Endotoxemia and adrenaline-hyperreactive death in mice. Experientia 34: 1483.

Lynch NR, Salomon J-C (1977) Passive local anaphylaxis: Demonstration of antitumor activity and complementation of intratumor BCG. J Natl Cancer Inst 58: 1093.

Männel DN, Rosenstreich DL, Mergenhagen SE (1979) Mechanism of lipopolysaccharide-induced tumor necrosis: Requirement for lipopolysaccharide-sensitive lymphoreticular cells. Infect Immun 24: 573.

Mattsson J, Appelgren L, Hamberger B, Petersson HI (1977) Adrenergic innervation of tumor blood vessels. Cancer Lett 3: 347 .

Munoz J, Bergman RK (1968) Histamine-sensitizing factors from microbial agents with special reference to Bordetella pertussis. Bact Rev 32: 103.

Nowotny A, Golub S, Key B (1971) Fate and effect of endotoxin derivatives in tumor-bearing mice. Proc Soc Exp Biol Med 136: 66 .

Parr I, Wheeler E, Alexander P (1973) Similarities of anti-tumour actions of endotoxin, lipid $A$ and double-stranded RNA. Br J Cancer 27: 370.

Pradhan SN, Achinstein B, Shear MJ (1957) Independence of drug-induced damage in sarcoma 37 and carotid blood pressure in mice. Arch Exp Pathol Pharmakol 230: 228.

Robbins SL, Cotran RS (1979) Fluid and hemodynamic derangements. In Pathologic Basis of Disease, 2nd edn. Eds. SL Robbins, RS Cotran. Philadelphia: Saunders. pp.107-140.

Rosenberg JC, Lillehei RC, Moran WH, Zimmermann B (1959) Effect of endotoxin on plasma catecholamines and serum serotonin. Proc Soc Exp Biol Med 102: 335.

Shapiro CJ (1940) The effect of a toxic carbohydrate complex from $S$. enteritidis on transplantable rat tumors in tissue culture. Am J Hyg 31 (B): 114.

Shear MJ, Turner FC, Perrault A, Shovelton T (1943) Chemical treatment of tumors. V. Isolation of the hemorrhage-producing fraction from Serratia marcescens (Bacillus prodigiosus) culture filtrates. $J$ Natl Cancer Inst 4: 81.

Siegel S (1959) The case of two independent samples. In Nonparametric Statistics for the Behavioural Sciences. Ed. HF Harlow. Tokyo: McGraw-Hill Kogakusha, pp. 95-158.

Weiner N (1980) Norepinephrine, epinephrine, and the sympathomimetic amines. In The Pharmacological Basis of Therapeutics. Eds. A Goodman Gilman, LS Goodman, A Gilman. New York: MacMillan, pp. 138-175.

Wickersham JK, Barlett WP, Furukawa SB, Puffer HW, Warner NE (1977) An evaluation of the response of the microvasculature in tumors on $\mathrm{C}_{3} \mathrm{H}$ mice to vasoactive drugs. Bibl Anat 15: 291 .

Zweifach BW, Nagler AL, Thomas L (1956) The role of epinephrine in the reactions produced by the endotoxins of gram-negative bacteria. II. The changes produced by endotoxin in the vascular reactivity to epinephrine in the rat mesoappendix and the isolated, perfused rabbit ear. $J$ Exp Med 104: 881 . 